\title{
High Net Worth Individual Investors: The Influencing Power and Position in Equity Markets
}

\author{
Dr. E. Uma Reddy \\ Assoc. Professor, CVR College of Engineering /H \& S Department (Mgt. Science), Hyderabad, India \\ Email: umareddy@cvr.ac.in
}

\begin{abstract}
As the High Net worth (HNI) Investors mount in the financial markets with great financial power, their footprint is clearly directing the Retail Investors. During the last decade Indian HNI Investor's exposure to the Mutual Funds and Primary Equity Market is not just substantial but also provides an early base to potential and stable capital Markets. Growth and sustainability of capital markets depend on wider participation of Retail Investors. The study concludes that Retail Investors are investing under the influence of HNI Investors Investments and the interaction of HNI and Institutional Investors is impacting them in a positive manner. There is a clear statistical evidence of HNI Investors influence on the investments of Retail Investors either in the primary market or the secondary market.
\end{abstract}

Index Terms: HNI Investors, Proprietary Trading, Assets under Management, IPO Subscription

\section{INTRODUCTION}

\section{Introduction to the HNI Investors}

High Net worth Individual (HNI) Investor's investment objectives is primarily concerned with the accumulation, preservation, and Liquidity of the wealth. HNI Investors employ wealth managers, financial advisors, and other financial experts to manage their wealth [3]. These experts provide various insights early on regulatory changes, locate investment and trading opportunities for further wealth creation. These investors are also privileged to have their own network and facilities to monitor the environmental factors to gauge the impact of these factors on the performance of overall corporate sector and financial markets [6].

HNIs Investment strategies certainly influence the other categories of Investors specifically the Retail Investors [2]. This influence includes the selection of asset mix and the amount of Investment. Investments in the mutual funds indicate the preference of various categories of Investors. Percentage of holding in the different asset classes is depicted in Table no: 1. This investment data of various categories of Investors not only indicate the level of investment in different asset classes but also indicate their investment preferences.
TABLE I.

INVESTOR CATEGORY Wise PERCENTAGE OF INVESTMENTS IN

\begin{tabular}{|l|l|l|l|l|l|}
\hline $\begin{array}{l}\text { Fund } \\
\text { category/Investors }\end{array}$ & $\begin{array}{l}\text { Corpora } \\
\text { te }\end{array}$ & $\begin{array}{l}\text { Ban } \\
\text { ks/F } \\
\text { I }\end{array}$ & FIIs & HNI & Retail \\
\hline $\begin{array}{l}\text { Liquid/Money } \\
\text { MarketFund/ floater }\end{array}$ & $\mathbf{7 8 . 5 3}$ & 3.68 & 0 & 15.72 & 2.06 \\
\hline $\begin{array}{l}\text { Gilt Fund Glit } \\
\text { Fund with 10 year } \\
\text { constant duration }\end{array}$ & $\mathbf{5 3 . 0 2}$ & 1.36 & 0.3 & 37.66 & 7.66 \\
\hline $\begin{array}{l}\text { Remaining } \\
\text { Income/Debt } \\
\text { Oriented Schemes }\end{array}$ & $\mathbf{5 9 . 7 3}$ & 2.2 & 0.11 & 34.47 & 3.49 \\
\hline $\begin{array}{l}\text { Growth/Equity } \\
\text { Oriented Schemes }\end{array}$ & 9.07 & 0.07 & 0.37 & 35.65 & $\mathbf{5 4 . 8 4}$ \\
\hline $\begin{array}{l}\text { Hybrid Schemes } \\
\text { (65\% of equity and } \\
\text { 35\% of Debt) }\end{array}$ & 13.73 & 0.07 & 0.26 & $\mathbf{6 2 . 9 7}$ & 22.96 \\
\hline Index Funds & 29.78 & 0 & 0 & $\mathbf{4 1 . 9 8}$ & 28.24 \\
\hline Gold ETF & $\mathbf{5 2 . 8 9}$ & 0.06 & 0 & 34.71 & 12.34 \\
\hline $\begin{array}{l}\text { ETFs(other than } \\
\text { Gold) }\end{array}$ & $\mathbf{9 2 . 3 2}$ & 1.44 & 0.03 & 4.88 & 1.32 \\
\hline $\begin{array}{l}\text { Fund of Funds } \\
\text { investing Overseas }\end{array}$ & 15.14 & 0.01 & 0 & $\mathbf{6 0 . 7 9}$ & 24.05 \\
\hline
\end{tabular}

Data Source: AMFI Quarterly AUM Data Dec-2020

\section{Retail Investors Trading turnover in the stock Market}

On an average Retail Investors Trading volume at NSE Equity Cash segment is $50.33 \%$ while Institutional Investors is $28.33 \%$ and Proprietary Trading volume is at $21.34 \%$. Chart 1 depicts Retail Investors Trading volume ranges from $48 \%$ to $53 \%$. Retail Investors trading turnover is gradually increasing during the study period indicating their confidence on prospects of the market. Large participation in the trading is desirable not only for stable Market but also the future prospect on different segments of the financial markets including primary market. 


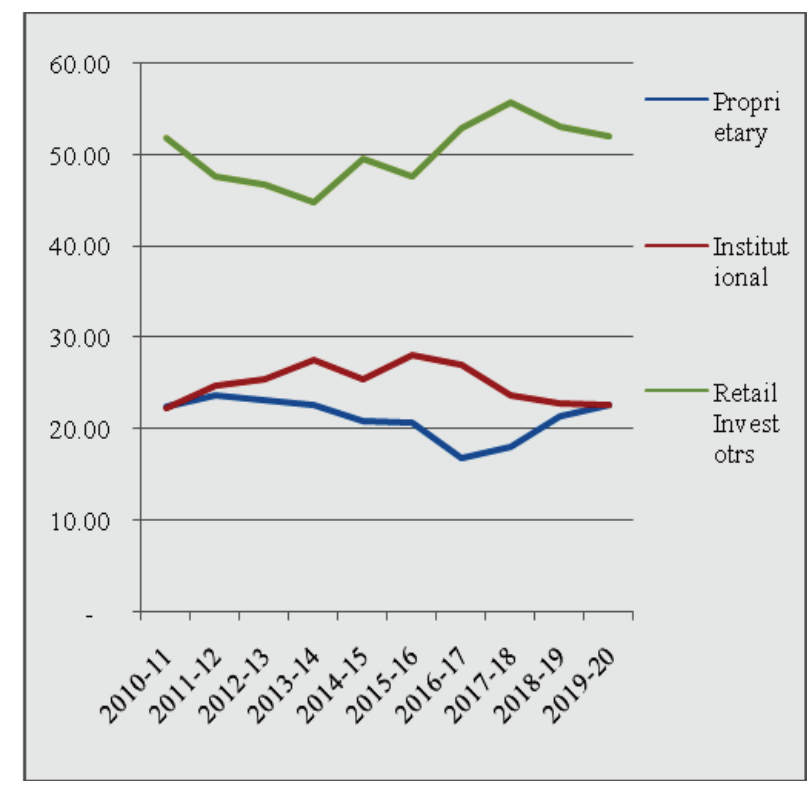

Chart 1: Category wise Percentage of Turnover in Equity Cash Segment Data Source: NSE Historical Turnover Data

Securities Exchange Board of India (SEBI) hosts various measures for large participation of retail investors in the market like creating positive environment and encouraging investments. Besides this, influence of other categories of Investors like institutional and HNI Investors investments inspire and boost the participation of Retail Investors. In the stock market it is widely believed that HNI and Institutional Investors possess more expertise and resources for effective investment decisions. Chart no. 2 indicates the influence of HNI and Institutional Investors on Retail Investors.

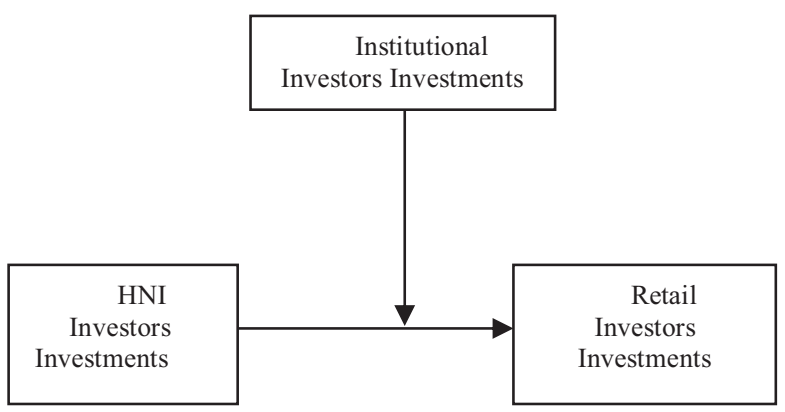

Chart no.2: Influence of HNI and Institutional (Moderating variable) investors Investments on Retail Investors Investments

Mutual fund Industry assets consist of investments in various categories which includes Equity, Debt, Hybrid, and different thematic funds. Chart 3 provides Assets Under Management (AUM) of Mutual Fund Industry contributed by various categories of Investors. There are 9,43,35,478 accounts in the mutual fund industry in December 2020, of which $90.1 \%$ is accounted for by the retail investors. There were $8,49,87,616$ Retail investor accounts with average ticket size of Rs 69,185 while there are 85, 59,664 HNI accounts, but with average ticket size of Rs 9,21,625. Institutional investors and HNI investors hold only $9.9 \%$ of Total Mutual accounts but contribute for $77.6 \%$ of AUM. Probing mutual fund AUM for identifying the influence of these two categories of Investors on Retail Category investments obviously help in understanding the requirements of these Investors for larger participation [1, 4].

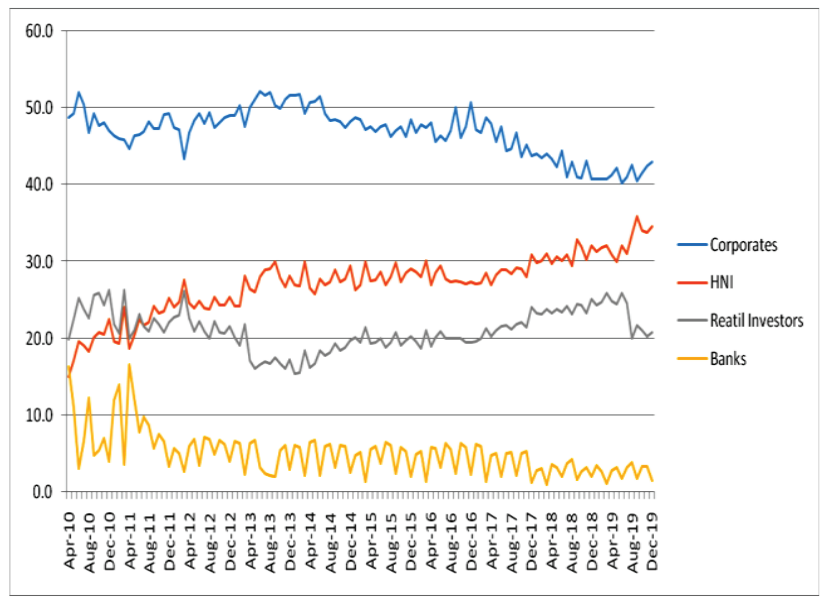

Chart 3: Percentage of AUM held by various categories of Investors. Data Source: AMFI Monthly Publications March 2020.

\section{Problem Statement}

Large number of Indian Retail Investors with small amount of Investment does not spend much time in analyzing the investment opportunities. This can be attributed to dearth of financial research information and analysis abilities. Therefore, they depend on Institutional and HNI Investors choice and simply follow the investment preferences of these categories of Investors. Research problem for the study stems from the Investment preferences of Retail Investors.

Hence the problem stated is 'under whose influence Retail Investors are making their Investment decisions'.

\section{DATA AND ReSEARCh Methodology}

Study uses published data from various regulatory agencies, Stock exchanges and financial Portals.

Time series data sets are used in the study includes

1) Quarterly category wise AUM Data during the period of March 2010 to December 2020

2) Yearly Category wise percentage of Turnover in Equity

Cash Segment during the period year2010-11 to 2019-20

3) IPO data of all 117 companies with issue size of Minimum

500 Crores of Rs during the period of December 2010 to December 2020.

Data sources: Association Mutual Funds in India (AMFI), NSE, SEBI

Study uses Moderation analysis which is a multiple Regression model to determine whether the relationship between two variables depends on (is moderated by) the value of a third variable. SPSS 21PROCESS Macro version 3.0 is used to determine the influence of third variable $(\mathrm{Z})$ on the relationship between two variables $(\mathrm{X}, \mathrm{Y})$. 


\section{IV.STUDY RESULTS}

i) Mutual fund Investments: Impact of HNI Investments on Retail Investors Investments under the influence of Corporate Investments

Model:

$\mathrm{Y}=\mathrm{B}_{0}+\mathrm{B}_{1} \mathrm{X}+\mathrm{B}_{2} \mathrm{Z}+\mathrm{B}_{3}(\mathrm{X} * \mathrm{Z})+\mathrm{e}$

Where

Y: RETAIL (Retail Investors Investments in Equity funds in thousands of rupees))

$\mathrm{X}$ : HNI(HNI Investors Investments)

Z: CORPO (Corporate Investors Investments)

Sample Size: 36

OUTCOME VARIABLE: RETAIL

TABLE II.

MODEL SUMMARY

\begin{tabular}{|ccccccc|}
\hline $\mathrm{R}$ & $\mathrm{R}-\mathrm{sq}$ & MSE & $\mathrm{F}$ & $\mathrm{df1}$ & $\mathrm{df2}$ & $\mathrm{p}$ \\
.995 & .990 & 165.157 & 1103.713 & 3.000 & 32.000 & .000 \\
\hline
\end{tabular}

\begin{tabular}{|lcccccr|}
\hline \multicolumn{7}{c|}{ MODEL } \\
constant & Coefficient & $\mathrm{se}$ & $\mathrm{t}$ & $\mathrm{p}$ & \multicolumn{1}{c|}{ LLCI } & ULCI \\
HNI & 101.418 & 8.702 & 11.654 & .000 & 83.691 & 119.145 \\
CORPO & .908 & .151 & 6.024 & .000 & .601 & 1.215 \\
Int_1 & .741 & .218 & -3.396 & .002 & -1.185 & -.296 \\
& .005 & .002 & 3.025 & .005 & .002 & .009 \\
\hline
\end{tabular}

Product terms key:

Int_1 : HNI $\mathrm{x}$ CORPORATE

Table no:2 indicates the model strength, Coefficient values and Lower and Upper level confidence intervals.

Coefficient value of constant in the model in the table no: 2 indicates that 101.4thousandsof rupees of Investments are independent of influencing variables i.e., HNI and/or Corporate investor's investments. HNI Investors investments are influencing the Retail Investors with the coefficient of 0.908. It indicates that each rupee of investment by HNI Investors obtain the investments of 0.91 rupee from Retail Investors.

TABLE III.

TEST(S) OF HIGHEST ORDER UNCONDITIONAL INTERACTION(S):

\begin{tabular}{cccccc}
\hline $\mathrm{X}$ & $\mathrm{R} 2$-change & $\mathrm{F}$ & $\mathrm{df1}$ & $\mathrm{df2}$ & $\mathrm{p}$ \\
& .003 & 9.149 & 1.000 & 32.000 & .005
\end{tabular}

Focal predict: HNI (X)

Moderating variable: CORPORATE $(\mathrm{Z})$

Table no $: 3$ indicates the interaction effect of HNI and Corporate Investors on Retail is strengthening the model with increased $R^{2}$ value.

TABLE IV

CONDITIONAL EFFECTS OF THE FOCAL PREDICTOR AT VALUES OF THE MODERATOR(S):

\begin{tabular}{|lcccccc|}
\hline Corporate & Effect & $\mathrm{se}$ & $\mathrm{t}$ & $\mathrm{p}$ & LLCI & ULCI \\
18.920 & 1.007 & .121 & 8.356 & .000 & .762 & 1.253 \\
62.500 & 1.236 & .062 & 19.901 & .000 & 1.109 & 1.362 \\
80.240 & 1.329 & .053 & 25.188 & .000 & 1.221 & 1.436
\end{tabular}

In the model summary direct influence of HNI Investments is indicated as coefficient 0.908 . However, this influence is higher at different levels of corporate investments. i.e. Table no: 4 values of Corporate at 16th, 50th, and 84th percentiles.

The Johnson-Neyman Technique is used to identify the range of values of the moderator (Corporate/QIB investments) in which the slope of the predictor (HNI Investments) is significant or not.

However the observed range of the moderator values are presented in Table No:5 which are identified by using the Johnson-Neyman method under the condition of below 0.05 significance level.

TABLE V.

Conditional EFFect of Focal Predictor at VALues of THE MODERATOR:

\begin{tabular}{|c|c|c|c|c|c|c|}
\hline \\
\hline Corporate & Effect & $\mathrm{se}$ & $\mathrm{t}$ & $\mathrm{p}$ & LLCI & ULCI \\
\hline 15.000 & .987 & .127 & 7.788 & .000 & .729 & 1.245 \\
\hline 18.750 & 1.006 & .121 & 8.330 & .000 & .760 & 1.252 \\
\hline 22.500 & 1.026 & .115 & 8.923 & .000 & .792 & 1.260 \\
\hline 26.250 & 1.046 & .109 & 9.572 & .000 & .823 & 1.268 \\
\hline 30.000 & 1.065 & .104 & 10.283 & .000 & .854 & 1.276 \\
\hline 33.750 & 1.085 & .098 & 11.065 & .000 & .885 & 1.285 \\
\hline 37.500 & 1.105 & .093 & 11.925 & .000 & .916 & 1.293 \\
\hline 41.250 & 1.124 & .087 & 12.869 & .000 & .946 & 1.302 \\
\hline 45.000 & 1.144 & .082 & 13.905 & .000 & .976 & 1.311 \\
\hline 48.750 & 1.164 & .077 & 15.036 & .000 & 1.006 & 1.321 \\
\hline 52.500 & 1.183 & .073 & 16.262 & .000 & 1.035 & 1.331 \\
\hline 56.250 & 1.203 & .068 & 17.576 & .000 & 1.063 & 1.342 \\
\hline 60.000 & 1.223 & .064 & 18.958 & .000 & 1.091 & 1.354 \\
\hline 63.750 & 1.242 & .061 & 20.374 & .000 & 1.118 & 1.366 \\
\hline 67.500 & 1.262 & .058 & 21.765 & .000 & 1.144 & 1.380 \\
\hline 71.250 & 1.282 & .056 & 23.056 & .000 & 1.168 & 1.395 \\
\hline 75.000 & 1.301 & .054 & 24.153 & .000 & 1.192 & 1.411 \\
\hline 78.750 & 1.321 & .053 & 24.963 & .000 & 1.213 & 1.429 \\
\hline 82.500 & 1.341 & .053 & 25.416 & .000 & 1.233 & 1.448 \\
\hline 86.250 & 1.360 & .053 & 25.486 & .000 & 1.252 & 1.469 \\
\hline 90.000 & 1.380 & .055 & 25.195 & .000 & 1.268 & 1.491 \\
\hline
\end{tabular}

Table no:5 and Chart no:4 indicates that at different range of Corporate Investments, influence of HNI Investments on Retail Investments. Coefficient values indicate that at higher levels of corporate investor's investments the influence of $\mathrm{HNI}$ investors is also high.

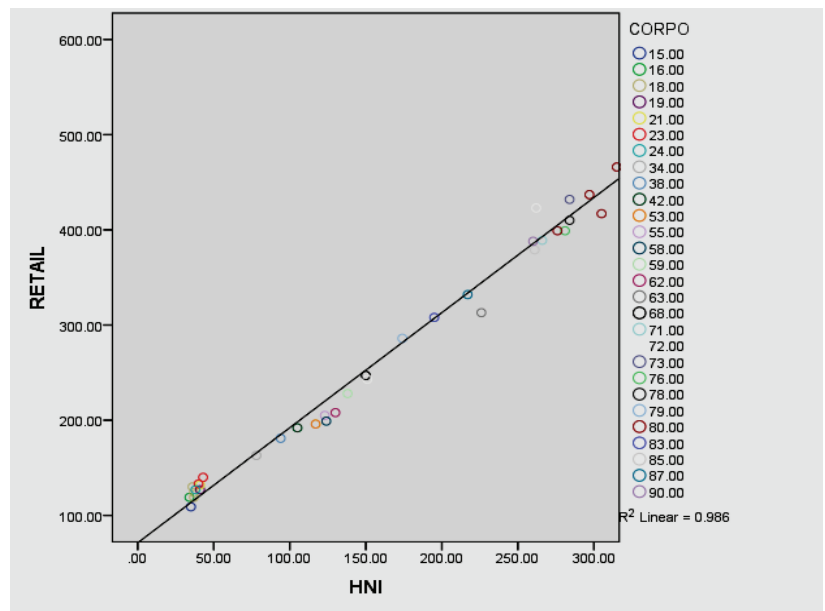

Chart no: 4 Influence of HNI investments on Retail Investment at various levels of Corporate Investments

\section{ii)IPO subscription trend in India}

In a primary market, the issuing company offers its equity to investors or groups and receives cash proceeds from the 
sale, which is then used to fund operations or expand the business. New public issues data presented in chart no 5 indicates that during the last decade there has been a considerable growth in number of public issues and capital formation. IPO Data is analyzed further to identify the category of Investors influencing other category like Retail Investors for the successful IPOs in the market [5]. IPO Subscription from various categories of investors in their respective quota is generally oversubscribed or undersubscribed as per the potentiality of the underlying company. Each category subscription rate in comparison with overall subscription rate indicates their confidence on the potentiality of the company. During the study period QIB, HNI and Retail Investors subscription rate correlates with overall subscription at $0.92,0.98$ and 0.74 respectively. This correlation indicates that QIB and HNI Investors play important role in the success of IPOs.

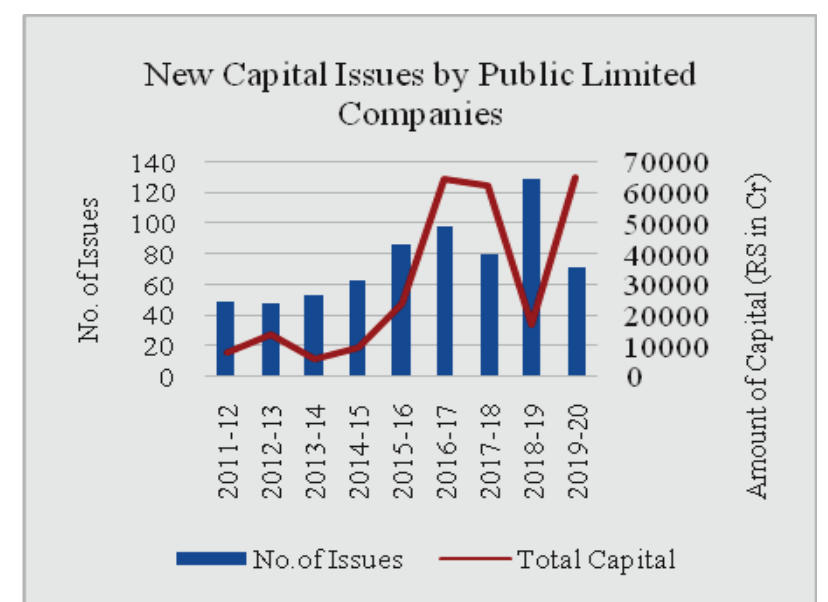

Chart 5. Initial Public Offers in India with no. of issues and amount of Capital raised.

Data Source: RBI Publications September 2020

iii)Impact of HNI Investor's subscription on Retail Investor's subscription under the influence of QIB Subscription rate

Moderation Analysis Test of SPSS Package is used for the conformity of HNI Investors effect on Retail Investors investments. This test is performed with IPO Subscription data by taking QIB Subscription as Moderating Variable.

Model: 1

Y: RETAIL (RETAIL Investors Subscription rate in IPO)

$\mathrm{X}$ : HNI (High Net Worth Investors IPO Subscription)

Z: QIB(Qualified Institutional Bidders IPO Subscription )

Sample Size: 117

OUTCOME VARIABLE: RETAIL
TABLE VI.

MODEL SUMMARY

\begin{tabular}{|c|c|c|c|c|c|c|}
\hline $\begin{array}{c}\mathrm{R} \\
.720\end{array}$ & $\begin{array}{r}\text { R-sq } \\
.519\end{array}$ & $\begin{array}{c}\text { MSE } \\
59.540\end{array}$ & $\begin{array}{c}F \\
40.660\end{array}$ & $\begin{array}{r}\mathrm{dfl} \\
3.000\end{array}$ & $\begin{array}{c}d f 2 \\
113.000\end{array}$ & $\begin{array}{r}\mathrm{p} \\
.000\end{array}$ \\
\hline \multicolumn{7}{|c|}{ MODEL } \\
\hline \multicolumn{2}{|c|}{ Coefficient } & se & $\mathrm{t}$ & $\mathrm{p}$ & LLCI & ULCI \\
\hline constant & 1.590 & .962 & 1.654 & .101 & -.315 & 3.495 \\
\hline HNI & .123 & .016 & 7.528 & .000 & .091 & .156 \\
\hline QIB & -.079 & .036 & -2.215 & .029 & -.149 & -.008 \\
\hline Int_1 & .000 & .000 & -2.910 & .004 & -.001 & .000 \\
\hline
\end{tabular}

Product terms key:

Int_1 : HNI $\quad$ Q

Model strength, Coefficient values and Lower and Upper level confidence intervals are presented in the Table no:6.

Coefficient value of constant in the model indicates that 1.59 times of IPO subscription of Retail Investors is independent of HNI and/or Corporate investor's subscription. However, this constant value is not statistically significant. Meanwhile HNI Investors subscription is influencing the Retail Investors with the coefficient of 0.123 and its significance level is below 0.001 . It implies that every one percent change in HNI Investors subscription influencing 0.123 percent change in Retail subscription.

TABLE VII.

TEST(S) OF HIGHEST ORDER UNCONDITIONAL INTERACTION(S):

\begin{tabular}{cccccr}
\hline & R2-change & $\mathrm{F}$ & $\mathrm{df1}$ & $\mathrm{df2}$ & $\mathrm{p}$ \\
$\mathrm{X} * \mathrm{Z}$ & .036 & 8.471 & 1.000 & 113.000 & .004
\end{tabular}

Focal predict: HNI (X)

Moderating variable: QIB $(\mathrm{Z})$

Table no :7 indicates the interaction effect of HNI and QIB Investors on Retail is strengthening the model with increased $R^{2}$ value.

TABLE VIII

Conditional EfFects Of The Focal Predictor At Values Of The MODERATOR(S):

\begin{tabular}{|llccccc|}
\hline QIB & Effect & $\mathrm{se}$ & $\mathrm{t}$ & $\mathrm{p}$ & LLCI & ULCI \\
2.333 & .123 & .016 & 7.569 & .000 & .090 & .155 \\
10.540 & .120 & .016 & 7.710 & .000 & .089 & .151 \\
64.674 & .102 & .012 & 8.326 & .000 & .077 & .126 \\
\hline
\end{tabular}

Table no: 8 presents HNI Investors influence at values of 16th, 50th, and 84th percentiles of QIB subscription. It indicates that at lower subscription rate of QIB there is higher effect of HNI Subscription on Retail Subscription.

Observed range of the moderator (QIB IPO Subscription rate) values are presented in Table No:9 in which the slope of the predictor (HNI IPO Subscription)) is significant. These values are identified by using the Johnson-Neyman method. Conditional effect Focal predict values are taken under the condition of below 0.05 significance level 
TABLE IX.

Conditional EFFect Of Focal Predictor At VAlues Of The MODERATOR

\begin{tabular}{|rlccccc|}
\hline QIB & Effect & $\mathrm{se}$ & $\mathrm{t}$ & $\mathrm{p}$ & LLCI & ULCI \\
.260 & .123 & .016 & 7.532 & .000 & .091 & .156 \\
9.860 & .120 & .016 & 7.699 & .000 & .089 & .151 \\
19.460 & .117 & .015 & 7.860 & .000 & .087 & .146 \\
29.060 & .114 & .014 & 8.010 & .000 & .085 & .142 \\
38.660 & .110 & .014 & 8.142 & .000 & .084 & .137 \\
48.260 & .107 & .013 & 8.245 & .000 & .081 & .133 \\
57.860 & .104 & .013 & 8.310 & .000 & .079 & .129 \\
67.460 & .101 & .012 & 8.324 & .000 & .077 & .125 \\
77.060 & .098 & .012 & 8.275 & .000 & .074 & .121 \\
86.660 & 094 & .012 & 8.154 & .000 & .071 & .117 \\
96.260 & .091 & .011 & 7.957 & .000 & .068 & .114 \\
105.860 & .088 & .011 & 7.685 & .000 & .065 & .111 \\
115.460 & .085 & .012 & 7.343 & .000 & .062 & .108 \\
125.060 & .081 & .012 & 6.946 & .000 & .058 & .105 \\
134.660 & .078 & .012 & 6.507 & .000 & .054 & .102 \\
144.260 & .075 & .012 & 6.046 & .000 & .050 & .100 \\
153.860 & .072 & .013 & 5.576 & .000 & .046 & .097 \\
163.460 & .069 & .013 & 5.110 & .000 & .042 & .095 \\
173.060 & .065 & .014 & 4.659 & .000 & .038 & .093 \\
182.660 & .062 & .015 & 4.229 & .000 & .033 & .091 \\
192.260 & .059 & .015 & 3.824 & .000 & .028 & .090 \\
& & & & & & \\
\hline
\end{tabular}

Moderation effect in the table no:9 and Chart no:6 indicates that at higher levels of QIB investor's subscription the influence of HNI investors is decreasing. However, HNI Investors influence is higher at lower subscription rate of QIB Investors.

Moderation effect which is significant at 0.01level graphically presented in the Chart no 6:

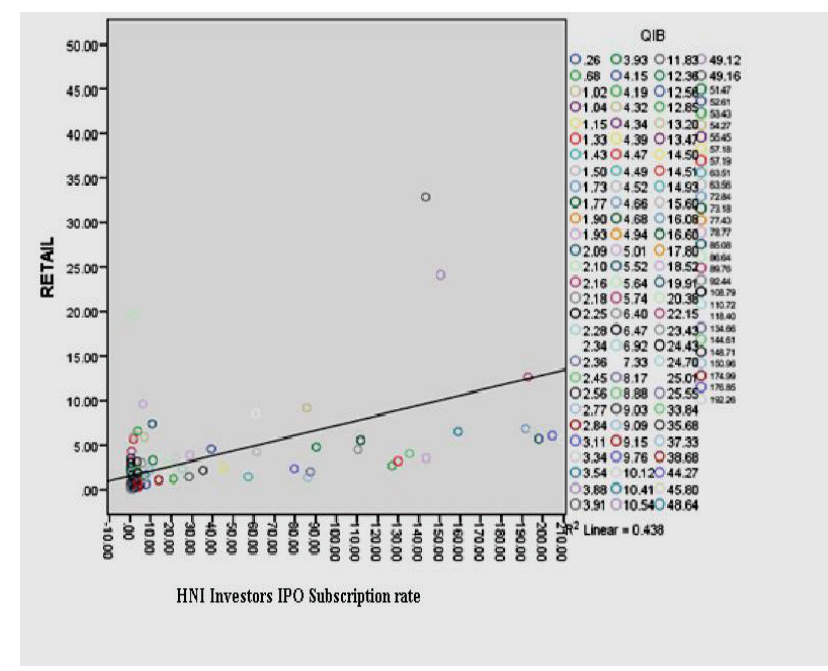

Chart no:6 Influence of HNIs IPO subscription rate on Retail subscription at various levels of QIBs IPO subscription.

Statistical evidence in the model summary and at different subscription rates of QIB Investors indicates that HNI Investors are playing important role in encouraging the Retail Investors at the time of low subscription from QIB Investors and rescuing the companies from under subscription or IPO failures.

\section{Conclusions}

High Net worth Individual Investors primary objective is always protection and maximization of their wealth through effective Investments. Investments data of HNIs in the primary and secondary markets of capital market clearly indicate their confidence on the potentiality of the Markets. HNI Investors selection of Assets and level of exposure to a particular investment avenue is clearly paving the way for the followers. HNI Investors subscription rate in IPOs is anchoring the successful capital formation for the business organizations and this matured primary market is essential for the growth of the economy and creating employment.

\section{REFERENCES:}

[1]. C. P. Chandrasekhar, Sarat Malik and Akriti The elusive retail investor: How deep can (and should) India's stock markets be?*The Securities and Exchange Board of India ,Development Research Group.PR No. 43/2016

[2]. Galstyan, A. (2021). Hnwis Investments: Trends And The Capacity To Attract (Visegrad Region Case Study). The Euraseans: Journal On Global Socio-Economic Dynamics, (1(26), 07-18.

[3]. Matt Christensen High Net Worth Individuals and Sustainable Investment - Part I Journal: Australian Journal of Financial PlanningISSN:1833-1106 Volume:4Issue:2 PP 19-25

[4]. Sharma, Kapil Mutual Fund Purchases by High Net Worth Individuals in India.Journal of Management Research (09725814) . Aug2006, Vol. 6 Issue 2, p59-71. 13p.

[5]. Thomas J. Chemmanur, Gang Hu, Jiekun Huang The Role of Institutional Investors in Initial Public Offerings The Review of Financial Studies, Volume 23, Issue 12, December 2010, PP 4496-4540,

[6]. "World Wealth Report 2020" Capgemini. Archived (PDF) from the original on 2020-11-10. Retrieved 2020-11-09. https:/www.capgemini.com/news/research-world-wealthreport-2020. 